\title{
Conservation agriculture systems for Malawian smallholder farmers: long-term effects on crop productivity, profitability and soil quality
}

\author{
Amos Robert Ngwira ${ }^{1 *}$, Christian Thierfelder ${ }^{2}$ and Dayton M. Lambert ${ }^{3}$ \\ ${ }^{1}$ Noragric, Norwegian University of Life Sciences, PO Box 5003, 1432 Ås, Norway. \\ ${ }^{2}$ CIMMYT, PO Box MP 163, Mount Pleasant, Harare, Zimbabwe. \\ ${ }^{3}$ Department of Agricultural \& Resource Economics, Institute of Agriculture, University of Tennessee, \\ 321 Morgan Hall, 2621 Morgan Circle, Knoxville, TN 37996-4518, USA. \\ *Corresponding author: robert.ngwira@umb.no
}

\begin{abstract}
Conservation agriculture (CA) systems are based upon minimal soil disturbance; crop residue retention and crop rotation and/or intercrop association are increasingly seen to recycle nutrients, increase yield and reduce production costs. This study examines the effects of CA practices on crop productivity, profitability and soil quality under the conditions encountered by smallholder farmers in two farming communities from 2005 to 2011 in Malawi, as part of the contribution to remedy a lack of supporting agronomic research for these relatively new systems. The drier agroenvironment of Lemu of Bazale Extension Planning Area (EPA) is characterized by sandy clay loam soils and lower rainfall. Here, CA showed positive benefits on maize yield after the first season of experimentation, with highest increases of $2.7 \mathrm{Mgha}^{-1}$ and $2.3 \mathrm{Mg} \mathrm{ha}^{-1}$ more yield in CA monocrop maize and CA maize-legume intercrop, respectively, than the conventional tillage in the driest season of 2009/10. In the high rainfall environment of Zidyana EPA (characterized by sandy loam soils), substantial maize yield benefits resulted in the fifth season of experimentation. Farmers spent at most 50 days ha $^{-1}$ (US\$140) producing maize under CA systems compared with 62 days $^{-1} \mathrm{a}^{-1}$ (US\$176) spent under conventional tillage practices. In Lemu, both CA systems resulted in gross margins three times higher than that of the conventional control plot, while in Zidyana, CA monocrop maize and CA maize-legume intercrop resulted in 33 and 23\% higher gross margins, respectively, than conventional tillage. In Zidyana, the earthworm population was highest (48 earthworms $\mathrm{m}^{-2}$ in the first $30 \mathrm{~cm}$ ) in CA monocrop maize, followed by a CA maize-legume intercropping (40 earthworms) and lowest (nine earthworms) in conventionally tilled treatment. In both study locations CA monocrop maize and CA maizelegume intercrop gave higher water infiltration than the conventional treatment. Improvements in crop productivity, overall economic gain and soil quality have made CA an attractive system for farmers in Malawi and other areas with similar conditions. However, for extensive adoption of CA by smallholder farmers, cultural beliefs that crop production is possible without the ubiquitous ridge and furrow system and residue burning for mice hunting have to be overcome.
\end{abstract}

Key words: no-tillage, maize yield, net returns, residue retention, infiltration, biological activity, herbicides

\section{Introduction}

Achieving the Millennium Development Goal (MDG) on poverty reduction will be challenging in the southern African region where a majority of the population depend on agriculture for their livelihood ${ }^{1}$. In Malawi, agriculture is the mainstay of the economy, contributing nearly $35 \%$ of the gross domestic product (GDP). Typical cultivated land holding sizes are $0.2-3$ ha and there is limited land area to expand agricultural production due to an increase in population growth ${ }^{2}$. The efficiency of crop productivity forms an essential component of improving food security. Maize is the major staple crop, occupying about 1.66 million hectares, translating to $80 \%$ of the land area under cultivation ${ }^{3}$ and accounting for more than $80 \%$ of the population's caloric intake ${ }^{4}$.

Over the past 25 years, average maize yields in Malawi remained low (Fig. 1) until 2005 when an ambitious

(C) Cambridge University Press 2012. The online version of this article is published within an Open Access environment subject to the conditions of the Creative Commons Attribution-NonCommercial-ShareAlike licence $<$ http://creativecommons.org/licenses/by-nc-sa/2.5/>. 


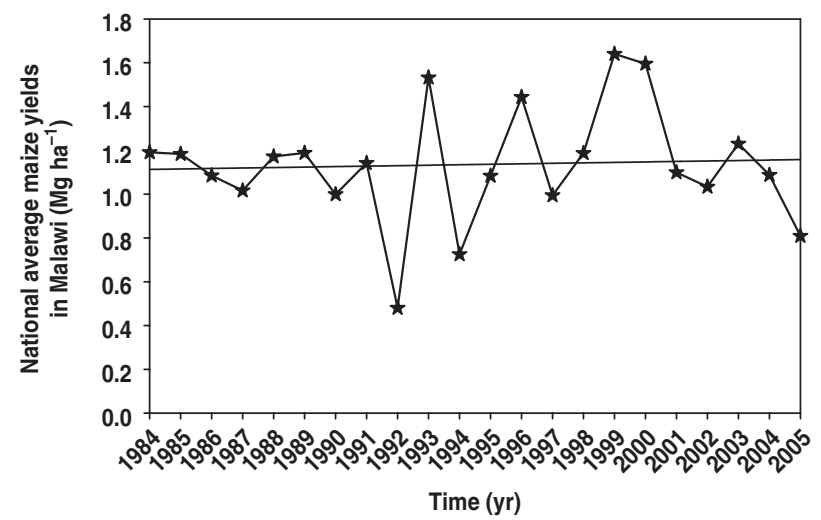

Figure 1. Average maize yields $\left(\mathrm{tha}^{-1}\right)$ in Malawi from 1982 to 2005 (MoAFS, $\left.2008^{4}\right)$.

smallholder Farm Input Support Program (FISP) was initiated. When fertilizer inputs increased, average maize yields jumped from approximately $1.1 \mathrm{Mgha}^{-1}$ in the $2004 / 05$ season to $1.6 \mathrm{Mgha}^{-1}$ in the $2005 / 06$ season $^{5}$. In the subsequent seasons, the estimated average maize yields were $2.6 \mathrm{Mg} \mathrm{ha}^{-1}$ (2006/2007), $1.6 \mathrm{Mg} \mathrm{ha}^{-1}$ (2007/ 2008), 1.7 $\mathrm{Mg} \mathrm{ha}^{-1}$ (2008/2009), 1.8 $\mathrm{Mgha}^{-1}$ (2009/2010) and $2.1 \mathrm{Mgha}^{-1}(2010 / 2011)$, respectively ${ }^{5,6}$. Some expressed concern about the sustainability of subsidized fertilizer and maize seed schemes, largely because of the high cost of inorganic fertilizer and the necessary budgetary support of the intervention ${ }^{7,8}$, but their huge impact on grain yield is beyond debate.

Despite the possibility of technological solution and policy support, agricultural productivity is limited by biotic and abiotic factors as well as institutional and socioeconomic constraints. For example, even when inputs are subsidized, the gap between the actual yield in Malawi $\left(\sim 1.2 \mathrm{Mgha}^{-1}\right)$ and attainable yield $\left(\sim 7 \mathrm{Mgha}^{-1}\right)$ is still very wide ${ }^{9}$.

In many farming systems, owing to continuous cropping, soil organic matter (SOC) contents have diminished to unsustainably low levels and are an important cause of low water and nutrient use efficiency and systems productivity ${ }^{10}$. Intensive soil tillage using hand hoes coupled with insufficient organic matter return to the soil are perceived as a major cause of land degradation ${ }^{11,12}$.

In Malawi, the ridge and furrow system, a farming method based on annually created raised seed beds, is labor intensive, reduces water infiltration due to hoe pans' and results in yield reductions over time ${ }^{13}$. These problems erode the benefits from crop genetic enhancement and further add to the increased risk of crop failure in times of frequent seasonal drought ${ }^{14}$.

This calls for sustainable production systems with more efficient use of resources and minimal environmental impact, while preserving the natural resource base dedicated to agriculture ${ }^{15}$.

Conservation agriculture (CA) is a sustainable cropping system that may help in reversing soil degradation, stabilizing and possibly increasing yield, and reducing labor time and producing a high net return. CA is based on three main principles: (1) minimum soil disturbance (i.e., direct sowing of crop seeds); (2) permanent soil cover with living or dead plant material; and (3) crop rotation or association with leguminous or cash crops for family use or sale ${ }^{16}$. CA systems practiced in southern Africa follow the general principle but other supporting management systems, such as manure, fertilizer, herbicides, early planting and row spacing, form part of the system. In most instances, use of herbicides is promoted within the CA package to control weeds, which become a nuisance especially in the initial years.

There are basically three different manual CA systems promoted and used in southern Africa besides animal traction (ripper tine and animal traction direct seeding systems) and tractor-drawn systems: the dibble stick, planting basins and jab-planters. Farmers in Malawi generally practice CA with the dibble stick, a pointed wooden stick, which aims at disturbing the soil as little as possible by only creating a planting hole where seeds are placed. Although planting basins and jab-planters are also promoted and have been tested, farmers in Malawi prefer the dibble-stick planting method because it is compatible with the traditional planting methods (i.e., planting the seed on the ridges is normally done with a pointed stick $)^{17}$.

The second method, used widely in Lesotho, Zambia and Zimbabwe, is based on manually dug planting basins ${ }^{18-20}$. Basins serve a common purpose of precision planting systems that support many other good agricultural management practices, such as timely planting or precision application of manure and fertilizers and better rainwater capture. The basins promoted are of various dimensions in different countries. The largest sizes are in Zambia $(40 \mathrm{~cm} \times 15 \mathrm{~cm} \times 18 \mathrm{~cm})$ where farmers aim at digging through hard pans, followed by those practiced in Lesotho $(15 \mathrm{~cm} \times 30 \mathrm{~cm} \times 20 \mathrm{~cm})$, with the smallest sizes in Zimbabwe $(15 \mathrm{~cm} \times 15 \mathrm{~cm} \times 15 \mathrm{~cm})$.

The third system is based on mechanical jab-planters originally developed by Brazilian manufacturers such as Fitarelli Machinas. The jab-planter has two compartments: one for fertilizer and one for seed and both are mounted on a wooden frame with two tips. Once the tips are pushed into the soil and opened by the operator seed and fertilizer drop into the planting hole. Although a jabplanter can seed in soils with crop residue retained as surface mulch, it has disadvantages such as clogging of the tips in sticky soil.

CA systems have been adopted by farmers in the USA, Latin America and Australia, mainly on large-scale commercial farms. For small-scale farmers in sub-Saharan Africa this cropping system is still new and areas under $\mathrm{CA}$ are small. Important documented benefits of CA, among others, include greater rainfall infiltration resulting in increased rainfall use efficiency ${ }^{21}$, early planting $^{18}$, reduced soil erosion ${ }^{19}$, increased soil biological activity ${ }^{14}$ and reduced labor hours per unit yield and hectare ${ }^{3,17,22}$. 


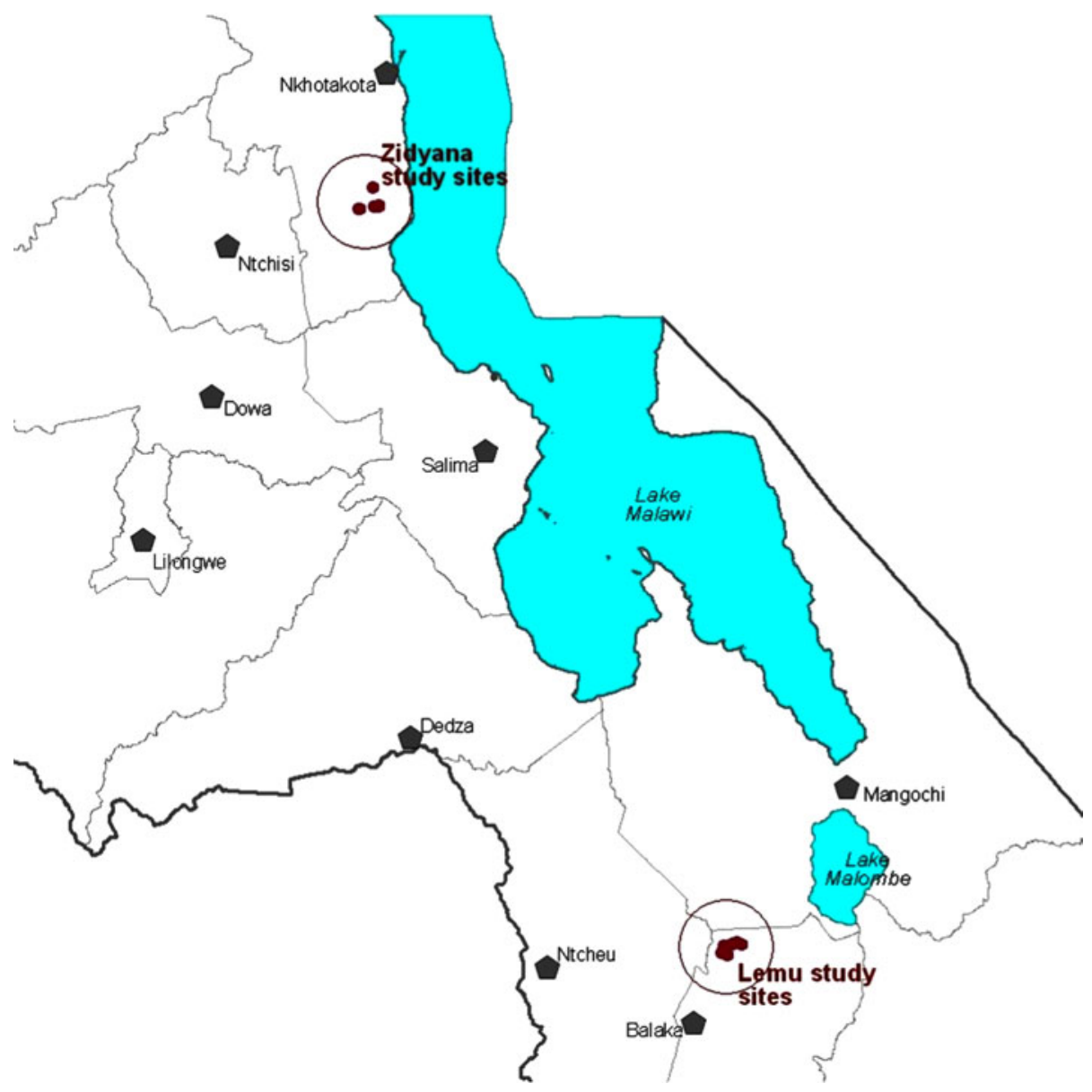

Figure 2. Map of central and southern Malawi showing study sites.

CA-oriented technologies were introduced in Malawi by Sasakawa Global 2000 (SG2000) in 1998, which was supported by the Malawian Government through a targeted input program (TIP) funded by various donor organizations $^{3}$. The major driver in this initiative was a set of management practices, which included denser plant population, specific herbicides for weed control and fertilization guidelines that were closely associated with the new governmental emphasis on input support. A direct consequence of the shift toward higher input agriculture and increased plant population densities was the increase in maize grain yield ${ }^{3}$. However, these past efforts concentrated on no-till and residue retention only, without any consideration for the part played by crop rotation or intercrop association.

The interest by the international research community, donors, non-governmental organizations (NGOs) and local governments in promoting $\mathrm{CA}$ as a widespread recommendation for small-scale farmers in sub-Saharan Africa has been contested by various authors ${ }^{19,23}$. These authors suggest that there is not enough scientific evidence about the putative benefits of CA to warrant large investment in widespread promotion of this new cropping system, and that CA would only fit into certain 'niches' under very specific circumstances ${ }^{19}$. Scientific evidence that supports the positive effects of CA compared with traditional tillage systems is based on the results of controlled experiments conducted on research stations that fail to represent smallholder production contexts and constraints ${ }^{24}$. This study therefore examines the effects of CA practices on crop productivity, profitability and soil quality under the conditions encountered by smallholder farmers in Malawi.

\section{Materials and Methods}

\section{Description of experimental sites}

This study was conducted over 6 years (2005-2011) in two communities of Lemu and Zidyana sections in the Bazale and Zidyana Extension Planning Areas (EPA), respectively. Lemu is located in Balaka district in the Machinga Agricultural Development Division $\left(14,79^{\circ} \mathrm{S}, 35,01^{\circ} \mathrm{E}\right.$, $720 \mathrm{~m}$ above sea level) (Fig. 2). Zidyana is located in Nkhotakota district in the Salima Agricultural Development Division $\left(13,23^{\circ} \mathrm{S}, 34,24^{\circ} \mathrm{E}, 532 \mathrm{~m}\right.$ above sea level). Both communities are characterized by a unimodal rainfall pattern with a rainy season from November to April, and mean annual rainfall of 935 and $1375 \mathrm{~mm}$ for Lemu and Zidyana, respectively. The 


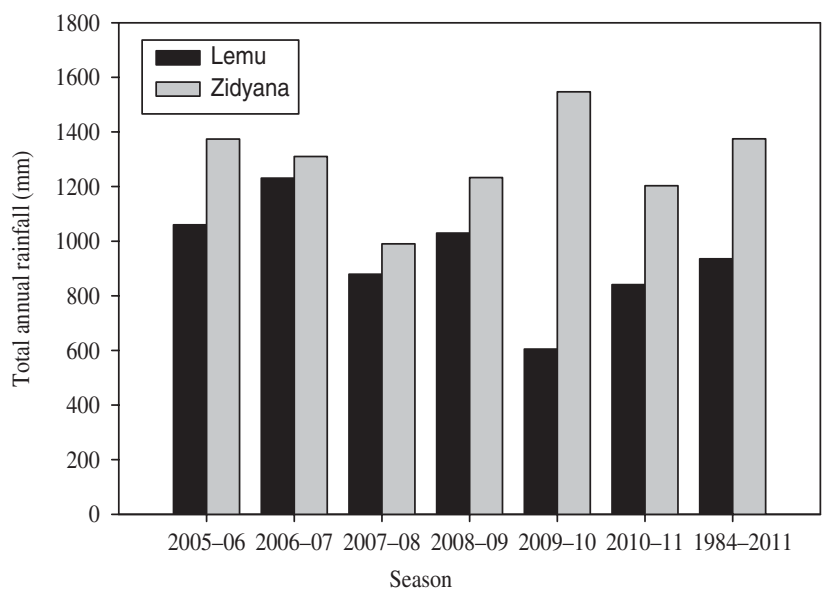

Figure 3. Total annual rainfall $(\mathrm{mm})$ recorded in different cropping seasons at a central point of validation trials in Lemu and Zidyana, Balaka and Nkhotakota district, respectively, 2006-11.

long-term average minimum and maximum temperatures during the growing season are 27 and $28^{\circ} \mathrm{C}$ for Lemu and Zidyana, respectively.

The dominant soil types found in both communities are Luvisols with sandy clay loam soils and sandy loam soils in Lemu and Zidyana, respectively, in the top $30 \mathrm{~cm}$ laye ${ }^{25}$. Mean annual rainfall $(\mathrm{mm})$ was higher in Zidyana as compared with Lemu during the study period (Fig. 3). Lemu received 330 and $94 \mathrm{~mm}$ less rainfall in the 2009/ 2010 and 2010/11 seasons, respectively, than the longterm average $(935 \mathrm{~mm})$. Zidyana received 385 and $172 \mathrm{~mm}$ less rainfall in 2007/08 and 2010/11 seasons, respectively, than the long-term average $(1375 \mathrm{~mm})$ during the research period.

\section{Experimental design}

The study was conducted on farmers' fields with a total of six farmers in each community hosting replicates of a validation trial spread across each target community. The main crop studied in both communities was maize (Zea mays L.) planted as a monocrop and intercropped with a legume in one treatment only. We report the results from 2005 to 2011 for maize in all years and legumes in some years when legumes were harvested.

Each farmer replicate was $3000 \mathrm{~m}^{2}$ in size, which was sub-divided into three treatments that were randomly allocated to plots, each covering an area of $1000 \mathrm{~m}^{2}$ as follows:

1. Conventional control plot consisting of traditional ridge and furrow land preparation planted with continuous monocrop maize (CPM). The residues were managed using methods commonly practiced in each EPA; i.e., the residues were incorporated into the ridges in Lemu and removed in Zidyana. Continuous monocrop maize was planted on the ridges.
2. CA plot with continuous monocrop maize (CAM) planted into the previous years' ridges (where they still existed) or directly into the plot without previous ridge formation. Crop residues from the previous years' harvests were retained as surface mulch. Maize seeds were planted as sole crops in no-till methods using a pointed stick (dibble stick).

3. CA plot with maize intercropped with a legume [cowpea (Vigna unguiculata L.) in Zidyana or pigeonpea (Cajanus cajan L.) in Lemu] (CAML). Both crops were planted with the dibble stick into the previous years' ridges (where they still existed) or directly into the plot without further ridging. Crop residues were retained as surface mulch as in treatment 2 .

\section{Trial management}

All of the trials were managed by farmers with support from extension officers and overseen by researchers in both target communities. Field staff and technicians provided plot management recommendations. Hybrid maize DKC8033 was used for the duration of the trials. The cowpea variety Sudan was grown in Zidyana and the pigeonpea variety ICEAP0040 in Lemu. All of the plots were seeded after the first effective rains (e.g., rainfall greater than $30 \mathrm{~mm}$ after November 15th). Ridges in the conventional tillage practice $(\mathrm{CP})$ were prepared by hand hoes around October in each year and crops were planted with hand hoes. Both legumes and maize were seeded at the same time. Ridge spacing was kept constant in the CA treatments: $75 \mathrm{~cm}$ between maize rows, $25 \mathrm{~cm}$ between planting stations and one living plant per station. The CPM plots followed normal spacing, planting pattern and planting population practiced by the farmers. In most cases, farmers have adopted the same $75 \times 25 \mathrm{~cm}$ plant spacing according to recommendations from Sasakawa Global $2000^{3}$. Intercropped legumes were seeded in between maize rows, planting two seeds spaced at 60 and $40 \mathrm{~cm}$ apart for pigeonpea and cowpea, respectively.

This study adopted a moderate fertilizer application of $69 \mathrm{~kg} \mathrm{Nha}^{-1}$, which is less than the recommended $92 \mathrm{~kg} \mathrm{Nha}^{-1}$. This lower fertilizer rate is used by most farmers who benefit from the farm input subsidy program implemented by the Malawi government because of recent government efforts to subsidize farm inputs to a significant proportion of farmers unable to acquire inputs on their own. This was supplied by applying $100 \mathrm{~kg} \mathrm{ha}^{-1}$ of $\mathrm{N}: \mathrm{P}: \mathrm{K}(23: 21: 0+4 \mathrm{~S})$ at seeding and $100 \mathrm{~kg} \mathrm{ha}^{-1}$ of urea $(46 \% \mathrm{~N})$ approximately 3 weeks after planting.

All of the CPM plots were manually weeded as necessary, whereas weeds in both CA treatments were controlled by spraying with herbicides followed by manual weeding later. In treatment 2 , after the first rain, annual and perennial weeds were killed by 2.5 liter ha $^{-1}$ glyphosate [N-(phosphono-methyl)glycine], applied 7-10 days before planting using a knapsack sprayer under the guidance of the field officer. Then, 3 days after 
planting, 6literha ${ }^{-1}$ Bullet $^{(B)}$ [Monsanto; containing $25.4 \%$ Alachlor (2-chloro-N-(2,6-diethylphenyl)-N(methoxymethyl) acetamide) and $14.5 \%$ atrazine (2chloro-4-ethylamino-6-isopropylamino-1,3,5-triazine)] was applied as pre-emergence herbicide, followed by manual weeding when the weeds were $10 \mathrm{~cm}$ tall or $10 \mathrm{~cm}$ in circumference. In treatment 3 , only 2.5 liter ha $^{-1}$ glyphosate was applied as a post-planting herbicide followed by manual weeding when the weeds were $10 \mathrm{~cm}$ tall or $10 \mathrm{~cm}$ in circumference. After three seasons, only 3 liter ha ${ }^{-1}$ of Bullet was necessary to control the broadleaved weeds. It was the field officer's role to train the farmers to handle herbicides carefully and safely, and to spray uniformly. Training also included familiarization with different herbicides, knapsack sprayers, nozzle types and protective clothing (e.g., a raincoat, gum boots, rubber gloves and respiratory masks). Our aim was to use herbicides on farmers' fields in the safest possible way but only to use herbicides in the first few years, i.e., the transition phase between conventional and CA systems, and to discontinue the use of herbicides once the weed pressure had declined or diminished. This was necessary to avoid the extra labor burden on women ${ }^{19}$.

\section{Harvest measurements}

At physiological maturity, maize was harvested from ten randomly selected samples of two rows $5 \mathrm{~m}$ long, collected from the middle of each treatment. The harvest area of the samples was used to extrapolate yields to an area basis. A sub-sample of 20 cobs per plot was dried and shelled to calculate grain yield at $12.5 \%$ moisture. All maize stalks and leaves without cobs were weighed at harvest; ten subsamples per plot were air dried at least 4 weeks before the final dry weights were taken and biomass was calculated on an area basis. For cowpea and pigeonpea, sequential harvesting was carried out once the crop reached physiological maturity; by putting the pods from each plot into respective sequential harvest bags and leaving them to air dry. Net plots of ten samples per treatment each consisting of two rows $5 \mathrm{~m}$ long were used to calculate the final harvest yields extrapolated to an area basis. Legume biomass was measured by taking a sample of ten stems per plot, cutting them into pieces and collecting a sub-sample of between 500 and $1000 \mathrm{~g}$. The subsample was weighed and air dried for at least 4 weeks before reweighing and was used to calculate biomass yield on an area basis. The rest of the biomass was returned to the field as surface mulch.

\section{Net returns calculations}

Net returns per hectare to each system were calculated using standard enterprise budgeting techniques to determine the production costs and profitability. A partial budget analysis was performed using labor data and prices of all applied inputs (seed, herbicides, fertilizers, etc.) from each of the plots during the entire period of the study. In order to improve the precision of the data, labor data (in person hours and minutes) were obtained from one on-farm trial per site for each operation (laying crop residue, tillage, herbicide application, planting, fertilizer application, weeding, harvesting, etc.). Labor data and prices for inputs were recorded for each treatment separately. Variable costs were recorded by extension workers working with farmers over the life of the project. Net return (profit)per hectare was estimated for each maize and legume yield $\left(\mathrm{kg} \mathrm{ha}^{-1}\right)$ observation produced by each system based on average farm gate prices of US\$ 0.21 and 0.71 (Lemu) and US\$ 0.23 and 0.34 (Zidyana) for maize and legume, respectively, and the average variable costs for each treatment during the study period $^{26}$. Maize prices were converted from Malawi Kwacha $\mathrm{kg}^{-1}$ to US\$ $\mathrm{kg}^{-1}$ using official exchange for this time posted by the Reserve Bank of Malawi [http:// www.rbm.mw/archive_dfbr.aspx (accessed October 17, 2011)]. This ensured comparability on a standard dollar $\mathrm{ha}^{-1}$ basis for different systems.

\section{SOC and aggregate stability}

SOC was determined using the method of Walkley and Black (cited by Van Reeuwijk ${ }^{27}$ ). This involves a wet combustion of the organic matter with a mixture of potassium dichromate and sulfuric acid. Soil samples were collected from three depth layers, 0-10, 10-20 and $20-30 \mathrm{~cm}$, in August 2011 from all treatments. A change in $\mathrm{SOC}$ as a result of CA was estimated by comparing soil samples from CA plots against CPM plots.

In order to convert percent SOC to $\mathrm{g} \mathrm{kg}^{-1}$ soil, bulk density measurements were measured from three depth layers, $0-10,10-20$ and $20-30 \mathrm{~cm}$, in August 2011. A composite sample was made from ten samples, each collected diagonally in the field from both furrows and ridges (where these still existed) or flat (where these ridges did not exist) under both CA systems, and ten samples from both ridges and furrows in conventional fields. At the time of sampling, the fresh residues were removed from the soil surface and the soil was air dried in the laboratory at Chitedze Research Station in Malawi. Disturbed soil samples were taken using a cylindrical sampling ring of known volume. The samples were oven dried at $105^{\circ} \mathrm{C}$ for $48 \mathrm{~h}$ in the laboratory. Bulk density was calculated as the mass of oven dried soil divided by total volume of soil. Surface soil samples were also taken from the same treatments in April 2011 from 0 to $30 \mathrm{~cm}$ depth; $50 \mathrm{~g}$ of a soil sub-sample was placed on a $2-\mathrm{mm}$ sieve and soaked for $10 \mathrm{~min}$ in water in the laboratory. After soaking, the samples were agitated in water for $10 \mathrm{~min}$ at 48 strokes $\mathrm{min}^{-1}$ with strokes of $35 \mathrm{~mm}$. Aggregates that remained on the sieve were dried at $105^{\circ} \mathrm{C}$ and weighed; and the percentages of water-stable aggregates were calculated. 


\section{Below-ground fauna}

Three soil monoliths of $25 \mathrm{~cm} \times 25 \mathrm{~cm} \times 30 \mathrm{~cm}$ depth were taken from each reported treatment in April 2011. The samples were divided into three depth layers, $0-10,10-20$ and $20-30 \mathrm{~cm}$, and hand sorted for macro-fauna (termites, earthworms, centipedes and others) and the numbers were counted $^{28}$.

\section{Time to pond and rainfall simulation measurements}

In the 2010/2011 season, a simple infiltration measurement, called 'time to pond ${ }^{.29}$ was carried out on each plot in both communities using a watering can and a metal ring of $50 \mathrm{~cm}$ diameter placed on the soil surface. The ring was irrigated at the center with a predetermined volume of water at a constant rate. Time to pond was calculated as the moment when water started to flow out of the ring. Infiltration measurements were carried out at all sites in the third season when the maize was at the grain-filling stage. These were replicated on five different sites on each treatment, mainly in the inter-row space; when the soil was at, or close to, field capacity. Twelve rainfall simulation measurements were carried out at each of the two communities simultaneously with time-to-pond measurements. The aim of this exercise was to calibrate time to pond with infiltration for a specific soil type of the two communities. Measurements of infiltration were carried out with a small rainfall simulator as described by Amézquita et al. (cited by Thierfelder and coworkers $^{14,21,30}$ ). Horton's infiltration model (Eq 1) was used to fit the data and to describe the exponential decay of the infiltration rate during the experiment.

$$
f_{\text {cap }}=\left(f_{0}-f_{\mathrm{c}}\right) \mathrm{e}^{-b t}+f_{\mathrm{c}}
$$

where $f_{\text {cap }}$ is the maximum infiltration capacity of the soil $\left(\mathrm{mm} \mathrm{h}^{-1}\right), f_{0}$ the initial infiltration capacity $\left(\mathrm{mm} \mathrm{h}^{-1}\right), f_{\mathrm{c}}$ the final infiltration capacity $\left(\mathrm{mm} \mathrm{h}^{-1}\right), b$ is Horton's constant and $t$ the elapsed time (h).

Final infiltration rates were plotted against time to pond and a linear model fitted to the data to obtain their relationship. This linear relationship was used to estimate total infiltration $(\mathrm{mm})$ specific for the soil type in each community (Fig. 4).

\section{Statistical analysis}

A linear mixed effects model (Restricted Maximum Likelihood) procedure ${ }^{31}$ was used to analyse data on yield, gross benefits, net returns, SOC, water infiltration, soil fauna, aggregate stability and bulk density from the on-farm trials. The farmers were considered to be random effects because the farmers were randomly selected from a wider population of farmers in each community to host non-replicated on-farm trials. The analysis of the mentioned soil quality and yield data was performed separately for Lemu and Zidyana communities because
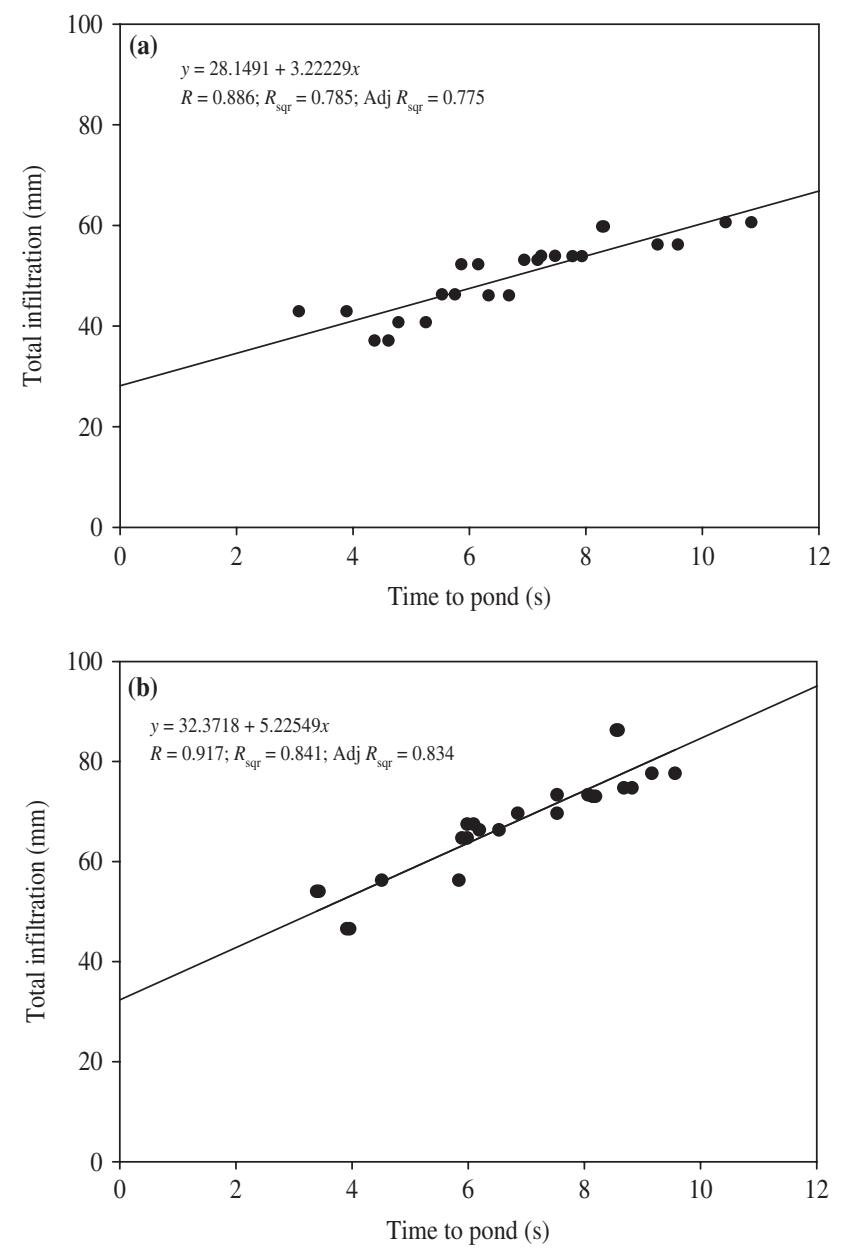

Figure 4. Total infiltration (mm) against time to pond (s) at Lemu (a) and Zidyana (b) in Balaka and Nkhotakota districts, respectively, Malawi, 2011.

the communities may not be the representatives of all possible communities in the study areas. Where significance was detected, the means were compared using the standard error of the difference (SED). Statistical analyses were performed using GenStat version $13^{32}$. Yield and soil quality data were tested for normality and homogeneity and showed normal population distribution and homogeneity of variance.

\section{Results}

\section{Maize and legume grain and total biomass yield}

On-farm evaluation of CA systems and conventional tillage practices (CPM) exhibited differing trends in maize yield among treatments across seasons at the two sites (Figs. 5a and 5b). In Lemu, the drier of the two sites, significant differences in maize grain yields were observed from the first cropping season onwards, with both CA systems being superior to CPM. Over the study period, the highest increase in maize yields between CA and CPM 

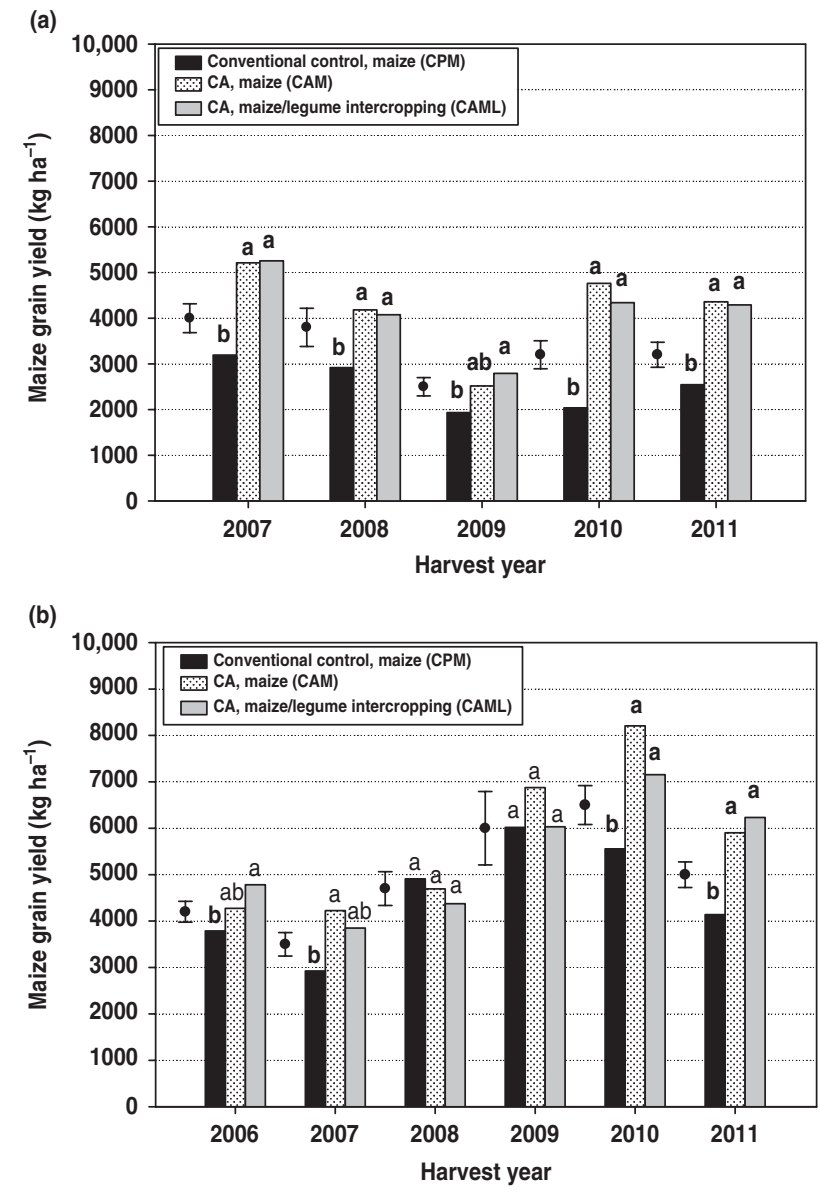

Figure 5. (a) Maize grain yields in conventional tilled, continuous maize, CA continuous sole maize and CA maizelegume intercrop located on farms in Lemu, Bazale EPA, Balaka district, southern Malawi. Error bars indicate standard error of the difference (SED). (b) Maize grain yields in conventional tilled, continuous maize, CA continuous sole maize and CA maize-legume intercrop located on farms in Zidyana EPA, Nkhotakota district, central Malawi. Error bars indicate standard error of the difference (SED).

was observed in 2009/10 season with 2.7 and $2.3 \mathrm{Mgha}^{-1}$, translating to 133 and $113 \%$ more yield in CAM and CAML, respectively, than CPM. The lowest increase in maize yields was observed in the 2008/09 season, with 0.6 and $0.9 \mathrm{Mg} \mathrm{ha}^{-1}$, translating to 30 and $44 \%$ more yield in CAM and CAML, respectively, than CPM.

There were no significant differences in maize yield in Zidyana during the first four cropping seasons. In the fifth season, maize yields were 48 and $29 \%$ higher in CAM and CAML, respectively, than CPM and in the sixth season CAM and CAML had 43 and 51\% higher maize grain yields, respectively, than CPM.

Total biomass production was significantly different between CPM and the two CA systems during 2006/07, 2009/10 and 2010/11 in both Lemu and Zidyana (Figs. 6a and $6 \mathrm{~b}$ ). The highest total biomass production during these cropping seasons was observed in the driest season
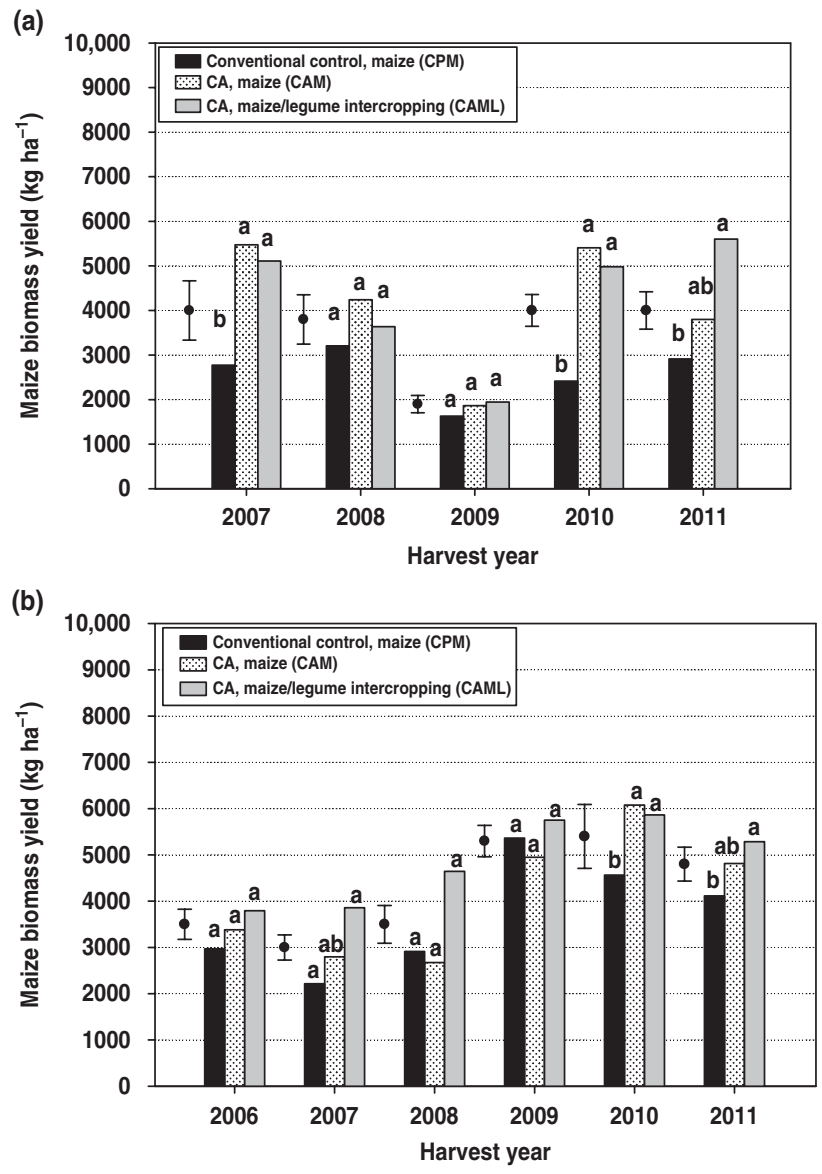

Figure 6. (a) Total biomass yields in conventional tilled, continuous maize, CA continuous sole maize and CA maizelegume intercrop located on farms in Lemu, Bazale EPA, Balaka district, southern Malawi. Error bars indicate standard error of the difference (SED). (b) Total biomass yields in conventional tilled, continuous maize, CA continuous sole maize and CA maize-legume intercrop located on farms in Zidyana EPA, Nkhotakota district, central Malawi. Error bars indicate standard error of the difference (SED).

of the study period of 2009/10 in Lemu, where CAM and CAML gave about 125 and $108 \%$, respectively, over CPM. In Lemu during 2010/11 when legume biomass was recorded, total biomass production from CAML gave about $47 \%$ more biomass over CAM. In Zidyana, CAM and CAML gave 33 and $28 \%$ more total biomass yield in 2009/10 and 2010/11, respectively, than CPM. Legume grain yield across seasons was significantly different in Lemu only (Table 1). Although data were only recorded during two out of five seasons, pigeonpea yield was significantly higher during $2009 / 10\left(0.6 \mathrm{Mgha}^{-1}\right)$ compared with $2010 / 11\left(0.5 \mathrm{Mgha}^{-1}\right)$.

\section{Net return analysis}

Since the two communities differed in terms of input cost and farm gate prices of maize and legume grain though 
Table 1. Pigeonpea and cowpea grain yield $\left(\mathrm{kgha}^{-1}\right)$ in Lemu and Zidyana communities in CA maize intercropped with grain legume, 2006-2011, Malawi.

\begin{tabular}{lll}
\hline Season & Lemu & Zidyana \\
\hline 2006 & N/A & $283.6 \mathrm{a}$ \\
2007 & N/A & $274 \mathrm{a}$ \\
2008 & N/A & $530 \mathrm{a}$ \\
2009 & N/A & $110 \mathrm{a}$ \\
2010 & $559.5 \mathrm{a}$ & $135 \mathrm{a}$ \\
2011 & $489.8 \mathrm{~b}$ & $226.7 \mathrm{a}$ \\
Standard errors & 142 & 67.26 \\
$P$-value & 0.043 & 0.487 \\
Wald statistic & 4.09 & 4.45 \\
\hline
\end{tabular}

Values followed by the same letter in each column belonging to the same site are not significantly different from each other at $P<0.05$.

N/A means that data were not available from farmers during that particular cropping season.

they had similar labor costs, separate profitability analyses for both sites are presented (Table 2). Farmers spent at most 50 daysha $^{-1}$ (US\$128) producing maize under CA systems compared with 62 days ha $^{-1}$ (US\$160) spent under $\mathrm{CP}$. However, the average variable costs were higher in CA systems compared with the conventional tillage due to additional costs for herbicide for weed control. Average input costs were US\$239, 341 and 354 for the conventional practices, CA sole maize and CA maize-pigeonpea intercrop, respectively, in Lemu and US\$222, 324 and 346 for the conventional practice, CA sole maize and CA maize-cowpea intercrop, respectively, in Zidyana. Nevertheless, average gross benefits were 67 and $85 \%$ higher in Lemu and 42 and $51 \%$ higher in Zidyana in CA sole maize and CA maize-legume intercrop, respectively, than conventionally tilled maize. In Lemu, both CA systems resulted in more than three times higher net returns compared with conventional tillage systems. In Zidyana, CA systems resulted in 32 and $23 \%$ higher gross margins with CA monocrop maize and CA maize-legume intercrop, respectively, than conventionally tilled maize. While significant differences in maize grain yields between conventional tillage and both CA systems were observed from the first season of experimentation in Lemu, net returns were significantly higher in the fourth and fifth seasons (Table 3). Net returns were 1222 and $1383 \%$ higher in CA sole maize and CA maizepigeonpea intercrop than conventional tillage in 2010, and 222 and $424 \%$ higher in CA sole maize and CA maize-legume intercrop than in conventional tillage in 2011. In Zidyana net returns were correlated with maize grain yield, with significant difference between the two CA systems and conventional tillage observed in the fifth and sixth seasons. Net returns were 63 and $35 \%$ higher in CA sole maize and CA maize-pigeonpea intercrop than conventional tillage in 2010, and 61 and $65 \%$ higher in CA sole maize and CA maize-legume intercrop than in conventional tillage in 2011. Both CA systems resulted in a more than doubled return to labor compared with $\mathrm{CP}$ in Lemu. In Zidyana, the CA monocrop maize and CA maize-legume intercrop systems resulted in 81 and $41 \%$, respectively, higher returns to labor than CPM.

\section{Total organic carbon}

Soil organic carbon ( $\mathrm{g} \mathrm{kg}^{-1}$ soil) measured at 0-10, 10-20, $20-30$ and $0-20 \mathrm{~cm}$ was not significantly different between CA and CPs $(P \leq 0.05)$ (Table 4). Although soil samples were collected from both furrows and the previous years' ridges (where these still existed) in CA plots, these were merged in the analysis because we did not observe any significant differences between them.

\section{Below-ground fauna}

Differences between treatments in the faunal groups of earthworm and termites were only observed in Zidyana (Table 5). At Lemu, spatial variability of these faunal groups was too large to detect any significant difference between treatments. In Zidyana, the earthworm population was highest $\left(48\right.$ earthworms $\mathrm{m}^{-2}$ ) in CAM, followed by CAML (40 earthworms $\mathrm{m}^{-2}$ ) and lowest $\left(9\right.$ earthworms $\mathrm{m}^{-2}$ ) in CPM treatment. At both sites centipede populations were higher in the top $30 \mathrm{~cm}$ of soil of CAM than CPM, whereas the rest of the faunal populations did not show significant difference between treatments.

\section{Infiltration and aggregate stability}

Calibrated infiltration rates from time to pond values measured in April 2011 showed significant differences between treatments at both study sites (Table 6). In Lemu, the highest total infiltration was recorded in CAML $(54 \mathrm{~mm})$ and CAM $(51 \mathrm{~mm})$ as compared with the CPM treatment $(43 \mathrm{~mm})$. This represents about 18 and $24 \%$ more infiltrated water on CAM and CAML, respectively, than in the CPM treatment. In Zidyana, total infiltration was higher in CAML $(75 \mathrm{~mm})$ and CAM $(74 \mathrm{~mm})$ than in CPM treatment $(52 \mathrm{~mm})$. About 41 and $42 \%$ more water entered into the soil profile in CAM and CAML treatment, respectively, than CPM. There were no significant differences in percent of water-stable aggregates between CPM and both CA systems at both sites for all classes (Table 6).

\section{Discussion}

\section{Maize grain and total biomass production}

Substantial maize yield increases were obtained by moving away from the ridge and furrow system that involved incorporation or removal of crop residue as compared with CA systems that retained all in-situ produced crop residue as surface mulch. Despite production 
Table 2. Farm Enterprise Budget Analysis for CA and CPs 2005-2011.

\begin{tabular}{|c|c|c|c|c|c|c|}
\hline & \multicolumn{3}{|c|}{ Lemu } & \multicolumn{3}{|c|}{ Zidyana } \\
\hline & $\mathbf{C P}$ & $\mathbf{C A}$ & CAL & $\mathbf{C P}$ & CA & CAL \\
\hline Gross receipts & 528.6 & 881.5 & 979.7 & 1047.2 & 1309.5 & 1293.7 \\
\hline \multicolumn{7}{|l|}{ Variable costs } \\
\hline Inputs & 238.5 & 341.0 & 353.6 & 221.7 & 323.7 & 346.1 \\
\hline Labor days (6h days) & 61.7 & 39.9 & 49.4 & 61.7 & 39.9 & 49.4 \\
\hline Labor costs & 159.5 & 103.2 & 127.9 & 155.6 & 100.7 & 124.7 \\
\hline Sprayer costs & & 1.7 & 1.2 & & 1.7 & 1.2 \\
\hline Total variable costs & 398.1 & 445.9 & 482.8 & 377.3 & 426.1 & 472.1 \\
\hline Net returns (US\$ ha ${ }^{-1}$ ) & 130.5 & 435.5 & 497.1 & 669.9 & 883.3 & 821.9 \\
\hline Returns to labor (US\$ per day) & 1.8 & 5.2 & 4.9 & 5.4 & 9.8 & 7.6 \\
\hline
\end{tabular}

Note: CP, conventional practice; CA, conservation agriculture sole maize; CAL, conservation agriculture maize-legume intercrop. Labor data (in person hours and minutes) was obtained from one on-farm trial per site for each operation (laying crop residues, tillage, herbicide application, planting, fertilizer application, weeding, harvesting, etc.).

Price data were based on all applied inputs (seed, herbicides, fertilizers, etc.) from each of the plots during the entire period of the study.

Table 3. Summary of gross benefits and net returns for each year in Lemu and Zidyana communities for CA and CPs $2005-2011$.

\begin{tabular}{|c|c|c|c|c|c|c|c|c|}
\hline Season & 2006 & 2007 & 2008 & 2009 & 2010 & 2011 & Mean & SD \\
\hline \multicolumn{9}{|c|}{ - } \\
\hline \multicolumn{9}{|l|}{ Lemu } \\
\hline CPM & N/A & $666.0 \mathrm{~b}$ & $607.7 \mathrm{~b}$ & $406.4 \mathrm{a}$ & $428.3 b$ & $534.4 \mathrm{c}$ & 528.6 & 111.9 \\
\hline CAM & N/A & $1090.0 \mathrm{a}$ & $873.1 \mathrm{a}$ & $528.8 \mathrm{a}$ & $1000.1 \mathrm{a}$ & $915.3 b$ & 881.5 & 213.9 \\
\hline CAML & N/A & $1098.0 \mathrm{a}$ & $851.0 \mathrm{a}$ & $586.6 \mathrm{a}$ & $1112.8 \mathrm{a}$ & $1250.1 \mathrm{a}$ & 979.7 & 262.6 \\
\hline SED & N/A & 103 & & & & & & \\
\hline \multicolumn{9}{|l|}{ Zidyana } \\
\hline CPM & $869.0 \mathrm{a}$ & $672.0 \mathrm{a}$ & $1129.0 \mathrm{a}$ & $1382.0 \mathrm{a}$ & $1278.0 \mathrm{~b}$ & $953.0 \mathrm{~b}$ & 1047.2 & 265.9 \\
\hline CAM & $981.0 \mathrm{a}$ & $972.0 \mathrm{a}$ & $1080.0 \mathrm{a}$ & $1579.0 \mathrm{a}$ & $1887.0 \mathrm{a}$ & $1358.0 \mathrm{a}$ & 1309.5 & 336.1 \\
\hline CAML & $1155.0 \mathrm{a}$ & $957.0 \mathrm{a}$ & $1126.0 \mathrm{a}$ & $1407.0 \mathrm{a}$ & $1676.0 \mathrm{a}$ & $1441.0 \mathrm{a}$ & 1293.7 & 305.3 \\
\hline SED & 151 & & & & & & & \\
\hline \multicolumn{9}{|c|}{-...-Net returns (US\$ ha $\left.{ }^{-1}\right)$} \\
\hline \multicolumn{9}{|l|}{ Lemu } \\
\hline CPM & N/A & $352.9 \mathrm{~b}$ & $100.4 \mathrm{a}$ & $-0.2 \mathrm{a}$ & $43.1 \mathrm{~b}$ & $156.3 \mathrm{c}$ & 130.5 & 137.6 \\
\hline CAM & N/A & $728.7 \mathrm{a}$ & $306.5 \mathrm{a}$ & $69.6 \mathrm{a}$ & $569.8 \mathrm{a}$ & $503.0 \mathrm{~b}$ & 435.5 & 254.5 \\
\hline CAML & N/A & $684.4 \mathrm{a}$ & $252.3 \mathrm{a}$ & $90.0 \mathrm{a}$ & $639.3 \mathrm{a}$ & $819.7 \mathrm{a}$ & 497.1 & 310.3 \\
\hline SED & N/A & 130 & & & & & & \\
\hline \multicolumn{9}{|l|}{ Zidyana } \\
\hline CPM & $562.9 \mathrm{a}$ & $359.5 \mathrm{a}$ & $622.2 \mathrm{a}$ & $975.3 \mathrm{a}$ & $892.7 \mathrm{~b}$ & $606.7 \mathrm{~b}$ & 669.9 & 226.7 \\
\hline CAM & $624.3 \mathrm{a}$ & $610.2 \mathrm{a}$ & $512.7 \mathrm{a}$ & $1120.3 \mathrm{a}$ & $1457.0 \mathrm{a}$ & $975.0 \mathrm{a}$ & 883.3 & 366.8 \\
\hline CAML & $746.7 \mathrm{a}$ & $542.8 \mathrm{a}$ & $527.7 \mathrm{a}$ & $910.5 \mathrm{a}$ & $1202.8 \mathrm{a}$ & $1000.8 \mathrm{a}$ & 821.9 & 266.5 \\
\hline SED & 151 & & & & & & & \\
\hline
\end{tabular}

Values followed by same letter within each column at the same site are not significantly different from each other at $P<0.05$.

$\mathrm{SD}$, standard deviation.

and retention of adequate levels of crop residue as surface mulch (which were assumed to be of poor quality in the monocrop CA maize system), CA did not have an adverse effect on crop yield for both soil types and rainfall regimes during the study period-attenuating concern that $\mathrm{N}$ immobilization may lead to lower crop yield, as suggested by other authors ${ }^{19}$. Since all of the plots received the same amount of fertilizer and maize varieties, we can surmise that differences between treatments are due to a combination of differences in tillage and land preparation methods, residue management, cropping systems and weed control strategies.

Greater nutrient and water use efficiency in CA systems than CPs could be assumed to have contributed to greater yields. In the drier environment of Lemu (characterized by sandy clay loam soils), most of the yield increase was observed in the driest year of 2009-10 (Fig. 5a) with 2.7 and $2.3 \mathrm{Mgha}^{-1}$ more maize obtained in the monocrop 
Table 4. Soil organic carbon $\left(\mathrm{g} \mathrm{kg}^{-1}\right.$ soil) in validation trials on farmers' fields consisting of conventional tillage, CA continuous sole maize and CA maize intercropped with grain legume after more than five seasons in Lemu and Zidyana sections, Balaka and Nkhotakota districts, Malawi, 2011.

\begin{tabular}{|c|c|c|c|c|c|c|}
\hline & \multicolumn{6}{|c|}{ Soil organic $\mathbf{C}$} \\
\hline & $0-10 \mathrm{~cm}$ & $10-20 \mathrm{~cm}$ & $20-30 \mathrm{~cm}$ & $0-10 \mathrm{~cm}$ & $10-20 \mathrm{~cm}$ & $20-30 \mathrm{~cm}$ \\
\hline & & Lemu & & & Zidyana & \\
\hline Conventional tillage & $14.26 \pm 3.56 \mathrm{a}$ & $12.96 \pm 5.67 \mathrm{a}$ & $12.26 \pm 5.77 \mathrm{a}$ & $9.11 \pm 4.40 \mathrm{a}$ & $6.40 \pm 3.05 \mathrm{a}$ & $5.47 \pm 2.31 \mathrm{a}$ \\
\hline CA sole maize & $15.41 \pm 5.29 \mathrm{a}$ & $15.81 \pm 6.36 \mathrm{a}$ & $13.26 \pm 5.48 \mathrm{a}$ & $8.61 \pm 4.37 \mathrm{a}$ & $6.71 \pm 3.82 \mathrm{a}$ & $5.75 \pm 2.92 \mathrm{a}$ \\
\hline CA maize-legume & $13.26 \pm 4.31 \mathrm{a}$ & $13.51 \pm 6.65 \mathrm{a}$ & $12.38 \pm 6.85 a$ & $10.62 \pm 4.42 \mathrm{a}$ & $7.49 \pm 1.57 \mathrm{a}$ & $6.12 \pm 1.60 \mathrm{a}$ \\
\hline Probability level & NS & NS & NS & NS & NS & NS \\
\hline
\end{tabular}

Values followed by the same letter in each column are not significantly different from each other at $P<0.05$.

Table 5. Below-ground fauna counts $\left(\mathrm{m}^{-2}\right)$ from 0 to $30 \mathrm{~cm}$ depth in validation trials on farmers' fields consisting of conventional tillage, CA continuous sole maize and CA maize intercropped with grain legume over five seasons in Lemu and Zidyana sections, Balaka and Nkhotakota districts, Malawi, 2011.

\begin{tabular}{|c|c|c|c|c|c|c|c|c|}
\hline \multirow[b]{2}{*}{ Treatments } & \multicolumn{4}{|c|}{ Lemu } & \multicolumn{4}{|c|}{ Zidyana } \\
\hline & Termites & Earthworms & Centipedes & Others* & Termites & Earthworms & Centipedes & Others $^{I}$ \\
\hline Conventional practice & $47 \mathrm{a}$ & $2 \mathrm{a}$ & $4 \mathrm{~b}$ & $16 \mathrm{a}$ & $46 b$ & $9 b$ & $6 b$ & $18 \mathrm{a}$ \\
\hline CA sole maize & $396 \mathrm{a}$ & $41 \mathrm{a}$ & $20 \mathrm{a}$ & $37 \mathrm{a}$ & $123 \mathrm{ab}$ & $48 \mathrm{a}$ & $18 \mathrm{a}$ & $33 \mathrm{a}$ \\
\hline CA maize/legume & $403 a$ & $42 \mathrm{a}$ & $12 \mathrm{ab}$ & $92 \mathrm{a}$ & $415 \mathrm{a}$ & $40 \mathrm{a}$ & $13 \mathrm{ab}$ & $31 \mathrm{a}$ \\
\hline Probability level (PF) & $5 \%$ & $5 \%$ & $5 \%$ & $5 \%$ & $5 \%$ & $5 \%$ & $5 \%$ & $5 \%$ \\
\hline
\end{tabular}

Values followed by same letter within each column are not significantly different from each other at $P<0.05$.

1 Others included white grubs, millipedes, red ants, etc.

CA maize system and the CA maize-legume intercrop system, respectively, than $\mathrm{CP}$. The substantial increase in maize yield in CA in Lemu from the first season could be attributed to a combination of minimum tillage and retention of crop surface residue as mulch. Mulch cover improved water infiltration even after the first season, especially under drier or moisture-limited conditions, thereby improving the effect on soil water balance in CA compared with $\mathrm{CPs}^{17,33,34}$. In this study, we showed that it was possible to produce and retain $2-5.5 \mathrm{Mgha}^{-1}$ of crop residues as surface mulch (Figs. $6 \mathrm{a}$ and $6 \mathrm{~b}$ ), thus providing a significant contribution to total biomass over conventional tillage systems, particularly in the last two seasons of the study period. Although we did not measure the amount of biomass remaining as surface mulch at the end of the winter season, the visual appraisal by the field staff suggested that a large portion of the residues could be retained as surface mulch despite an abundance of termites and prevailing warm and moist conditions in both study areas. Crop residue retained as surface mulch in the range of $4-6 \mathrm{Mgha}^{-1}$ has been suggested to alter rainwater infiltration ${ }^{34}$. In the wetter environment of Zidyana, characterized by sandy loam soils, significant differences in maize yield between CA and CP were only apparent after 4 years of experimentation. The results of this study suggest that in marginal environments, such as that of Lemu, benefits from CA are realized earlier compared with environments with optimal conditions for crop production, such as Zidyana.
A time lag between investment in CA and tangible benefits has been reported ${ }^{35}$. Such information is important for farmers because they expect tangible benefits in a relatively short time period when changing to new agriculture systems ${ }^{19}$. Some studies have reported difficulty in retaining crop residues as surface mulch, largely due to competition with livestock, particularly during the dry season when communal grazing is common ${ }^{20,36}$. In most parts of Malawi, very few farmers own livestock. Therefore, the potential seems higher for significant adoption of crop residue retention as surface mulch in CA in most areas of Malawi. In some areas, crop residues are traditionally burned to clear fields of residue and to facilitate the hunting of rodents (a significant source of protein and income). Competing use of maize stover include use as a fuel source for fire-sterilizing tobacco nursery beds against soilborne diseases; a cooking fuel source, as trees are scarce in the context of deforestation; and for fencing gardens. Farmers in some areas expressed concern about spreading crop residues in cases where termites or white grubs are common. Thus, community use of crop residue may be an important impediment to continued adoption of CA.

\section{Maize and legume intercropping}

Neither legume crop appeared to compete with the maize crop, as there was no significant difference in maize yields between CA sole maize and CA maize-legume intercrop 
Table 6. Soil aggregate stability $(\%)$ and infiltration $(\mathrm{mm})$ in validation trials on farmers' fields consisting of conventional tillage, CA continuous sole maize and CA maize intercropped with grain legume over five seasons in Lemu and Zidyana sections, Balaka and Nkhotakota districts, Malawi, 2011.

\begin{tabular}{|c|c|c|c|c|c|c|}
\hline \multirow[b]{2}{*}{ Treatment } & \multicolumn{5}{|c|}{ Aggregate stability (\%) } & \\
\hline & \multicolumn{5}{|c|}{ Class } & \\
\hline Lemu & 0.5 & 1 & 2 & 4.75 & 10 & Infiltration (mm) \\
\hline Conventional practice & $64.4(10.9)$ & $40.5(11.9)$ & $40.52(25.6)$ & $6.8(4.9)$ & $9.4(12.2)$ & $43.1 \mathrm{~b}$ \\
\hline CA sole maize & $65.9(11.3)$ & $49.0(22.4)$ & $37.8(18.4)$ & $4.2(2.8)$ & $5.5(5.0)$ & $50.8 \mathrm{a}$ \\
\hline CA maize/legume & $58.5(5.9)$ & $53.3(16.8)$ & $41.2(18.5)$ & $4.5(3.4)$ & $12.1(12.1)$ & $53.6 \mathrm{a}$ \\
\hline Probability level (PF) & NS & NS & NS & NS & NS & $5 \%$ \\
\hline Zidyana & 0.5 & 1 & 2 & 4.75 & 10 & Infiltration (mm) \\
\hline Conventional practice & $63.42(19.1)$ & 49.1(13.3) & $43.1(15.8)$ & $10.3(11.7)$ & $9.0(15.0)$ & $52.3 \mathrm{~b}$ \\
\hline CA sole maize & $68.72(10.1)$ & $51.8(16.7)$ & $38.0(15.5)$ & $18.2(11.2)$ & $4.6(10.1)$ & $73.9 \mathrm{a}$ \\
\hline CA maize/legume & $64.53(12.0)$ & $50.2(10.1)$ & $32.1(29.6)$ & $8.4(5.6)$ & $2.6(6.4)$ & $74.5 \mathrm{a}$ \\
\hline Probability level (PF) & NS & NS & NS & NS & NS & $5 \%$ \\
\hline
\end{tabular}

Values followed by the same letter in each column for infiltration are not significantly different from each other at $P<0.05$.

Values in parentheses indicate standard deviations.

(Figs. 5a and 5b). Thus, the selected legume crops may be considered a 'bonus' in CA systems, although weed control can be more challenging with this system. Other studies have demonstrated a significant contribution to biomass production by intercropping maize with cereals compared with monocrop cereals ${ }^{17,24,37}$. Although farmers planted the type of legumes adapted to their local context, the grain yields obtained were lower than the potential. ICEAP00040 pigeonpea ${ }^{38}$ and Sudan 1 cowpea $^{39}$ cultivars have a yield potential of 1.6 and $1.8 \mathrm{Mgha}^{-1}$, respectively, when grown on farm, whereas the range in this study was $0.5-0.6 \mathrm{Mg} \mathrm{ha}^{-1}$ for pigeonpea in Lemu and $0.1-0.5 \mathrm{Mgha}^{-1}$ for cowpea in Zidyana. This difference (between potential yield and actual yield obtained in this study) was probably due to an inadequate number of sprays against insect pests such as aphids (Aphis gossypii) and elegant grasshoppers (Dichromorpha elegans) as well as dry spells causing flower abortion.

There was also a large variability in terms of legume management by farmers. In Lemu, pigeonpea was harvested in some cases earlier than the harvest data could be captured. Therefore, productivity gains in terms of pigeonpea yield and total biomass in CAML was underestimated for those seasons when pigeonpea data were missing.

Of the two legumes, pigeonpea grain has a high demand in Malawi and India (an export market from Malawi), and the stems are used as fuelwood ${ }^{40,41}$. Although not measured in this study, there are additional benefits of intercropping maize with legumes. Pigeonpea intercropped with maize can add up to $60 \mathrm{~kg} \mathrm{Nha}^{-1}$ through nitrogen fixation without additional labor requirements ${ }^{40}$. Pigeonpea, with its deep taproots, may assist in breaking the widespread hoe pans prevalent in most smallholder farmers' fields in Malawi, thus improving soil structure and porosity. These changes created by roots could allow more water to infiltrate the soil instead of ponding on the soil surface. The mixing of maize residue that is of low quality, and higher quality residues from legumes, could potentially reduce the $\mathrm{C}: \mathrm{N}$ ratio by increasing the nitrogen component in the relation, thus avoiding temporary $\mathrm{N}$ immobilization by micro-organisms ${ }^{42,43}$.

A critical CA component in Malawi will be the 'rotation' principle. The land holdings of typical farmers are too small to dedicate land to serial rotational cropping systems, and intercropping might be the only reasonable alternative to venture into diversification. The ability of suitable intercrops such as cowpea or pigeonpea to reduce pests and diseases has not been adequately investigated or sufficiently understood ${ }^{14}$. Farmers are also hesitant to grow more legumes if there are no readily available markets for the sale of produce ${ }^{14,40,44}$.

\section{Profitability analysis}

Both CA systems resulted in higher net returns compared with CPs from the fourth season in Lemu and from the fifth season in Zidyana. Although farmers did not achieve substantial profit in CA systems during the initial years of the experiment, CA offers some socio-economic benefits even with similar net returns in the two systems. Producing maize using CA required fewer labor days than CPs. Labor savings of 35 and $20 \%$ were achieved in the monocrop CA maize system and CA maize-legume intercrop systems, respectively. The higher labor requirement for $\mathrm{CP}$ is primarily due to land preparation and weed control. Our discussion with farmers revealed that farmers used the saved labor to grow other crops, such as groundnuts, paprika, cotton, rice and horticultural crops, as well as to allow women more time to participate in local markets. 
Under CA, producers are expected to save between 9 and 19 days in land preparation and weeding, respectively. A similar analysis of no-till cropping involving planting basins in Zimbabwe reported more labor days to produce maize under CA compared with $\mathrm{CPs}^{45}$. Planting basin CA is perceived as a more labor intensive form of CA than the dibble-stick technique used in this study. Nevertheless, higher total variable costs were realized in the CA systems compared with the conventional practice (at most US\$483 in CA versus US\$398 in CP in Lemu and at most US\$883 in CA versus US\$670 in CP in Zidyana). This is mainly due to higher input costs for different herbicides and sprayers used in those treatments. The additional costs that need to be considered when introducing CA systems are the investment for herbicides, knapsack sprayers and protective gear. However, farmers can cooperatively buy and share the latter to reduce costs. Although it can be argued that production costs can be offset by higher gross margins realized under CA systems, incurring additional capital costs could be a disincentive for adoption of CA for the majority of smallholder farmers in Sub-Saharan Africa and, in particular, Malawi ${ }^{46,47}$.

In Lemu both CA systems resulted in more than three times higher gross margins compared with conventional tillage systems. In Zidyana, CA systems resulted in 32 and $23 \%$ higher gross margins with CA monocrop maize and CA maize-legume intercrop, respectively, than conventionally tilled maize. The cost of producing $1 \mathrm{~kg}$ of maize is lower with CA systems, earning more than double the return to labor than with the conventional farmer practices (Table 2). Higher gross margins, the lower cost of producing $1 \mathrm{~kg}$ of maize, and higher returns to labor have been reported under conservation farming in Zimbabwe ${ }^{45}$. The prime driver of CA adoption by smallholder farmers in other regions is profitability and the reduction of risk $^{22}$.

\section{Soil quality}

On-farm validation trials showed that CA systems led to an increase in abundance of soil fauna and infiltration compared with CPs. The retention of a large quantity of crop residue produced in-situ in combination with minimum tillage was sufficient to increase water infiltration and thereby reduce runoff and stimulate macro-fauna activity $^{14,19,48,49}$. The increase in the macro-fauna has been previously reported to create a large number of channels that aid in water infiltration ${ }^{50}$. Higher soil organic carbon and aggregate stability have been reported in CA systems with crop residue retained as surface mulch than conventional tilled systems with residue incorporated in long-term experiments in Mexico ${ }^{51,52}$. However, this was not the case in our study. We suspect soil sampling at different depths led to insignificant differences in soil $\mathrm{C}$ between CA and CPM fields. In Malawi ridges in CPM plots are often $30 \mathrm{~cm}$ deep and since the CA fields become flat after years of no ridge making, there might be differences in the depths sampled. We therefore propose improvements in soil sampling procedures when a comparison is made between soil samples taken from the ridges and from the flat.

\section{Conclusion}

On-farm validation trials in central and southern Malawi found that CA systems increased maize yield, net return and soil quality compared with CPs. Application of the three principles of CA, i.e., minimum tillage, retention of crop residue as surface mulch and crop association appeared to be vital for these benefits. In the drier environment of Lemu, CA yielded positive benefits on maize yield from the first season onwards, while it took longer in the wetter environment of Zidyana EPA. Differences in maize grain yield in Zidyana were only apparent after 4 years of experimentation. Labor savings of $35 \%$ were achieved in CA sole maize and $20 \%$ in the CA maize-legume intercropping system as compared with the conventional control, coupled with increased yields which make CA more profitable. Higher variable costs (for herbicides and spraying) can be offset by the farmers through higher net returns realized under CA. Nevertheless, for a majority of the smallholder farmers in Malawi the additional capital costs for inputs can be a disincentive for CA adoption. Therefore, farmers will require support from NGOs, the public and the private sector to offset higher incremental costs of adoption of CA. CA increased water infiltration and below-ground fauna (e.g., earthworms and termites) in the locations analyzed. Lack of an absolute increase in soil organic carbon content points to a gradual increase in soil fertility under the different CA systems because surface-placed crop residues are less exposed to microbial attack. The study finds that associating maize with grain legumes appears to be a more viable option of CA than crop rotation for farmers with limited land-holding sizes and food security concerns. However, the effect of different intercrops on eliminating pest and disease cycles is poorly understood and needs further research. Although our results showed a potential increase in productivity in CA than CPs using a standard package, there is a need to link these to farmer resource endowment and differing biophysical conditions. Nonetheless, CA appears to be a promising system for small-scale farmers to sustainably increase food production in Malawi.

Acknowledgements. We thank the farmers, the Total Land Care staff and the Agricultural Extension Development Officers (AEDO) of Lemu and Zidyana sections for their enthusiasm, collaboration and support during the project implementation phase. Special thanks go to John Chisui, Richard Museka, Mphatso Gama, Florence Kamwana and Pacsu Simwaka for their tireless efforts in coordinating project activities. We also wish to acknowledge the International Maize and Wheat Improvement Centre (CIMMYT) for logistical support and the German Technical Cooperation (GTZ), the International Fund for Agriculture Development (IFAD) and the Royal 
Norwegian Embassy through the Agricultural Research and Development Program (ARDEP) for funding project activities.

\section{References}

1 Love, D., Twomlow, S., Mupangwa, W., Van der Zaag, P., and Gumbo, B. 2006. Implementing the millennium development food security goals - challenges of southern Africa context. Physics and Chemistry of the Earth 31:731-737.

2 Ellis, F., Kutengule, M., and Nyasulu, A. 2003. Livelihoods and rural poverty reduction in Malawi. World Development 31:1495-1510.

3 Ito, M., Matsumoto, T., and Quinones, M.A. 2007. Conservation tillage practice in sub-Saharan Africa: the experience of Sasakawa Global 2000. Crop Protection 26:417-423.

4 Ministry of Agriculture, Irrigation and Food Security, MoAFS. 2008. Annual Agricultural Statistical Bulletin. Planning Division. Government of Malawi. Lilongwe, Malawi.

5 Denning, G., Kabambe, P., Sanchez, P., Malik, A., and Flor, R. 2009. Input subsidies to improve smallholder maize productivity in Malawi: toward an African Green Revolution. PLoS Biol 7:e1000023.

6 Ministry of Agriculture and Food Security, MoAFS 2011. Crop Production Estimates. Ministry of Agriculture and Food Security. Planning. Government of the Republic of Malawi, Lilongwe.

7 Mann, C. 1998. Higher yields for all smallholders through 'best-bet' technology: the surest way to restart economic growth in Malawi: Network Research Results Working Paper No. 3. CIMMYT, Mexico.

8 Levy, S. (ed.) 2005. Starter Packs: a Strategy to Fight Hunger in Developing Countries? CABI Publishing, Wallingford.

9 Kumwenda, J.D.T., Waddington, S.R., Snapp, S.S., Jones, R.B., and Blackie, M.J. 1998. Soil Fertility Management in Southern Africa. In D. Byerlee and C.K. Eicher (eds). Africa's Emerging Maize Revolution. Lynne Reiner Publishers, Colorado. p. 157-172.

10 Montgomery, D.R. 2007. Dirt: The Erosion of Civilization. University of California Press, Berkley, California. p. 295.

11 Wall, P. 2007. Tailoring conservation agriculture to the needs of small farmers in developing countries: an analysis of issues. Journal of Crop Improvement 19:137-155.

12 Rockström, J., Kaumbotho, P., Mwalley, J., Nzabi, A.W., Temesgen, M., Mawenya, L., Barron, J., Mutua, J., and Damgaard-Larsen, S. 2009. Conservation farming strategies in East and Southern Africa: yields and rain water productivity from on-farm action research. Soil and Tillage Research 103:23-32.

13 Materechera, S.A., and Mloza-Banda, H.R. 1997. Soil penetration resistance, root growth and yield of maize as influenced by tillage system on ridges in Malawi. Soil and Tillage Research 41:13-24.

14 Thierfelder, C., and Wall, P.C. 2010. Rotation in conservation agriculture systems of Zambia: effects on soil quality and water relations. Experimental Agriculture 46:309-325.

15 Hobbs, P.R., Sayre, K., and Gupta, R. 2008. The role of conservation agriculture in sustainable agriculture. Philosophical Transactions of the Royal Society Biological Sciences 363:543-555.
16 FAO, 2011. Conservation Agriculture. 2011-08-09. Available at http://www.fao.org/ag/ca/index.html (accessed July 30, 2012).

17 Ngwira, A.R., Aune, J.B., and Mkwinda, S. 2012. On-farm evaluation of yield and economic benefit of short term maize legume intercropping systems under conservation agriculture in Malawi. Field Crops Research 132:149-152.

18 Haggblade, S., and Tembo, G. 2003. Development, diffussion and impact of Conservation Farming in Zambia. Working Paper No. 8. Food Security Research Project, Lusaka, Zambia. p. 76.

19 Giller, K.E., Witter, E., Corbeels, M., and Tittonell, P. 2009. Conservation Agriculture and smallholder farming in Africa: the heretics' view. Field Crops Research 114: 23-34.

20 Umar, B.B., Aune, J.B., Johnsen, F.H., and Lungu, O.I. 2011. Options for improving smallholder conservation agriculture in Zambia. Journal of Agricultural Sciences 3:50-62.

21 Thierfelder, C., and Wall, P.C. 2009. Effects of conservation agriculture techniques on infiltration and soil water content in Zambia and Zimbabwe. Soil and Tillage Research 105:217-227.

22 Sorrenson, W.J., Duarte, C., and Lopez Portillo, J. 1998. Economics of no-tillage compared to traditional cultivation on small farms in Paraguay, Asunción. MAG/GTZ Soil Conservation Project. p. 15.

23 Bolliger, A. 2007. Is zero-till an appropriate agricultural alternative for disadvantaged smallholders of South Africa? A study of surrogate systems and strategies, smallholder sensitivities and soil glycoproteins. PhD thesis, University of Copenhagen. p. 67.

24 Baudron, F., Tittonell, P., Corbeels, M., Letourmy, P., and Giller, K.E. 2011. Comparative performance of conservation agriculture and current smallholder farming practices in semi-arid Zimbabwe. Field Crops Research 132:117-128.

25 WRB, 1998. World Reference Base on Soils. FAO-ISRIC, Rome, Italy. p. 88.

26 Bewick, L.S., Young, F.L., Alldrege, J.R., and Young, D.L. 2008. Agronomics and economics of no-till facultative wheat in the Pacific Northwest, USA. Crop Protection 27:932-942.

27 Van Reeuwijk, L.P. 1987. Procedures for soil analysis. International Soil Reference and Information Centre (ISRC), Wageningen, The Netherlands.

28 Anderson, J.M., and Ingram, J.S.I. 1993. Tropical Soil Biology and Fertility: A handbook of Methods. 2nd ed. C.A. B. International, Wallington, UK. p. 221.

29 Govaerts, B., Sayre, K.D., and Deckers, J. 2006. A minimum data set for soil quality assessment of wheat and maize cropping in the highlands of Mexico. Soil and Tillage Research 87:163-174.

30 Thierfelder, C., Amezquita, E., and Stahr, K. 2005. Effects of intensifying organic manuring and tillage practices on penetration resistance and infiltration rate. Soil and Tillage Research 82:211-226.

31 Coe, R. 2007. Analyzing data from participatory on-farm trials. African Statistical Journal 4:89-112.

32 Genstat. 2010. GenStat Release 13.3 (GeneStat 13th ed.). VSN International Ltd, Oxford.

33 Roth, C.H., Meyer, B., Frede, H.G., and Derpsch, R. 1988. Effects of mulch rates and tillage systems on infitrability and 
other soil physical properties of an oxisol in Parana, Brazil. Soil Tillage Research 11:81-91.

34 Derpsch, R. 1988. Effects of mulch rates and tillage systems on infitrability and other soil physical properties of an oxisol in Parana, Brazil. Soil and Tillage Research $1: 81-91$.

35 Luo, Z., Wang, E., and Sun, O.J., 2010. Can no-tillage stimulate carbon sequestration in agricultural soils? A metaanalysis of paired experiments. Agriculture, Ecosystems \& Environment 139:224-231.

36 Mtambanengwe, F., and Mapfumo, P. 2005. Organic matter management as an underlying cause for soil fertility gradients on smallholder farms in Zimbabwe. Nutrient Cycling in Agroecosystems 73:227-243.

37 Naudin, K., Gozé, E., Balarabe, O., Giller, K.E., and Scopel, E. 2010. Impact of no tillage and mulching practices on cotton production in North Cameroon: a multi-locational on farm assessment. Soil and Tillage Research 108:68-76.

38 Silim, S.N., Gwata, E.T., Mligo, J.K., Siambi, M., Karuru O., King, S.B., and Omanga, P. 2005. Registration of pigeonpea cultivar 'ICEAP00040'. Crop Science 45:2647.

39 Mazuma, E.D.L., Muyombe, M.C., Andersiki, R.B., and Pungulani, L. 2008. Screening cowpea varieties for resistance to predominant cowpea diseases and high yielding ability. DARS Annual Planning Meeting, Mangochi, 14-19 September, 2008, p. 31-43.

40 Myaka, F.M., Sakala, W.D., Adu-Gyamfi, J.J., Kamalongo, D., Ngwira, A., Odgaard, R., Nielsen, N.E., and HøghJensen, H. 2006. Yields and accummulations of $\mathrm{N}$ and $\mathrm{P}$ in farmer-managed intercrops of maize-pigeonpea in semi-arid Africa. Plant Soil 285:207-220.

41 Høgh-Jensen, H., Myaka, F.A., Kamalongo, D., Rasmussen, J., and Ngwira, A., 2006. Effect of environment on multi-element grain composition of pigeonpea cultivars under farmers' conditions. Plant Soil 285:81-96.

42 Adu-Gyamfi, J.J., Myaka, F.A., Sakala, W.D., Odgaard, R., Vesterager, J.M., and Hoghjensen, H. 2007. Biological nitrogen fixation and nitrogen and phosphorus budgets in farmer managed intercrops of maize-pigeonpea in semi-arid southern and eastern Africa. Plant Soil 295:127-136.
43 Sakala, W.D., Cadisch, G., and Giller, K.E. 2000. Interactions between residues of maize and pigeonpea and mineral $\mathrm{N}$ fertilizers during decomposition and $\mathrm{N}$ mineralisation. Soil Biology and Biochemistry 32:679-688.

44 Snapp, S.S., Rohrback, D.D., Simtowe, F., and Freeman, H. A. 2002. Sustainable soil management options for Malawi: can smallholder farmers grow more legumes? Agriculture Ecosystystems and Environment 91:159-174.

45 Mazvimavi, K., and Twomlow, S. 2009. Socioeconomic and institutional factors influencing adoption of conservation agriculture by vulnerable households in Zimbabwe. Agricultural Systems 101:20-29.

46 Gowing, J.W., and Palmer, M. 2008. Sustainable agricultural development in sub-Saharan Africa: the case for a paradigm shift in land husbandry. Soil Use and Management 24:92-99.

47 Giller, K.E., Corbeels, M., Nyamangara, J., Triomphe, B., Affholder, F., Scopel, E., and Tittonell, P. 2011. A research agenda to explore the role of conservation agriculture in African smallholder farming systems. Field Crops Research 124:468-472.

48 Mando, A., Brussaard, L., and Stroosnijder, L. 1999. Termite- and mulch-mediated rehabilitation of vegetation on crusted soil in West Africa. Restoration Ecology 7:33-41.

49 McGarry, D., Bridge, B.J., and Radford, B.J. 2000. Contrasting soil physical properties after zero and traditional tillage of an alluvial soil in the semi-arid subtropics. Soil and Tillage Research 53:105-115.

50 Bescansa, P., Imaz, M.J., Virto, I., Enrique, A., and Hoogmoed, W.B. 2006. Soil water retention as affected by tillage and residue management in semiarid Spain. Soil and Tillage Research 87:19-27.

51 Govaerts, B., Sayre, K.D., Goudedeune, B., De Corte, P., Lichter, K., Dendooven, L., and Deckers, J. 2006. Conservation Agriculture as a sustainable option for the central Mexican highlands. Soil and Tillage Research 103:222-230.

52 Verhulst, N., Nelissen, V., Jespers, N., Haven, H., Sayre, K.D., Raes, D., Deckers, J., and Govaerts, B. 2011. Soil water content, maize yield and its stability as affected by tillage and crop residue management in rainfed semi-arid highlands. Plant Soil 344:73-85. 